\title{
The effect of one-dose package on medication adherence for the elderly care in Japan
}

\author{
Kiyohito NAKAI, Nobuo YAMAMOTO, Miwako KAMEI, Masahiko FUJITA. \\ Received (first version): 31-Oct-2008 Accepted: 22-Dec-2008
}

\begin{abstract}
${ }^{*}$
Deterioration of the medication adherence for elderly could result in wasteful medical expenditure in a long-term span as well as aggravating the patient's medical condition.

Objective: This study surveyed the effect of onedose package medication made up by a pharmacist on the patient's behavior towards medication, what is expected to be one of the measures to improve the medication adherence for elderly. Methods: With support activity of the Pharmacist Association in Ueda-city in Nagano Prefecture, Japan, the survey form of one-dose package was sent to 86 pharmacy directors located in Ueda-city. Results: The most frequent reasons of one dose packaging was "Patient's request" though, "Large number of doses", "Prevent the improper drug use" and "Improved medication adherence" which is considered that the pharmacists are willing to utilize one dose package for patient's care in order to improve the medication adherence were chosen as well. The influences of one dose package for patient's medication adherence were very positive, and most answers indicated that medication adherence was improved.

Conclusion: It is noticed that the pharmacists were willing to dispense one dose packaging by own decision, not physician's order, in order to improve the medication adherence, prevent improper drug use and optimize the medication therapy. It is also noticed that there are great improvement of patient's compliance by one dose package, and patients felt advantage to reduce the improper drug use as well.
\end{abstract}

Keywords: Drug Packaging. Community Pharmacy Services. Medication Adherence. Japan.

\footnotetext{
"Kiyohito NAKAI. Ph.D. Researcher of Social Pharmacy, School of Pharmaceutical Sciences, Showa University. Tokyo (Japan).

Nobuo YAMAMOTO. R.Ph. Researcher of Social

Pharmacy, School of Pharmaceutical Sciences, Showa University. Tokyo (Japan).

Miwako KAMEI. Ph.D. Professor of Social Pharmacy, School of Pharmaceutical Sciences, Showa University. Tokyo (Japan).

Masahiko FUJITA. Ph.D. Researcher, Division of Safety Information on Drug, Food and Chemicals, National Institute of Health Sciences. Tokyo (Japan).
}

\author{
EFECTO DE LOS ENVASES DE DOSIS \\ UNITARIA EN LA ADHERENCIA A LA \\ MEDICACIÓN DE LOS ANCIANOS EN \\ JAPÓN
}

\section{RESUMEN}

El deterioro de la adherencia a la medicación en ancianos podría producir desperdicio del gasto médico a largo plazo así como agravar el estado de salud de los pacientes.

Objetivo: Este estudio investigó los efectos de los paquetes de dosis unitarias hechos por farmacéuticos sobre la actuación de los pacientes sobre la medicación, lo que se espera que sea una de las medidas que mejoren la adherencia a la medicación en los ancianos.

Métodos: Con el apoyo de la Asociación de Farmacéuticos de Ueda en la Prefectura de Nagano (Japón), se envió por fax a 86 directores de farmacia el cuestionario y las respuestas se recogieron por fax en junio de 2007.

Resultados: La razón más frecuente de la realización de los envases de dosis unitaria fue "la demanda del paciente", aunque también eligieron como respuesta "Gran numero de dosis", "prevenir el uso inadecuado" y "Mejora de la adherencia a la medicación", lo que da idea de que los farmacéuticos están dispuestos a utilizar los envases de dosis unitaria para que mejore la adherencia a la medicación de sus pacientes. Las influencias del envase de dosis unitaria sobre la adherencia a la medicación fueron muy positivas, y la mayoría indicó que mejoró la adherencia a la medicación.

Conclusión: Se puede evr que los farmacéuticos estaban dispuestos a dispensar envases de dosis unitarias por su propia decisión, sin orden del médico, para mejorar la adherencia a la medicación, prevenir uso inapropiado de medicamentos, y optimizar el tratamiento farmacológico. También se ve que existe una gran mejoría en el cumplimiento del paicente con los envases de dosis unitaria, y los pacientes también sienten que reducen su uso inadecuado de medicamentos.

Palabras clave: Envases de medicamentos. Servicios de farmacias comunitarias. Adherencia a la medicación. Japón. 


\section{INTRODUCTION}

One dose package medication is that pharmacist dispenses plural medicines as one-dose package so as able to take the medicines at each dosing time such as after meal or before sleep (Figure 1). ${ }^{1}$

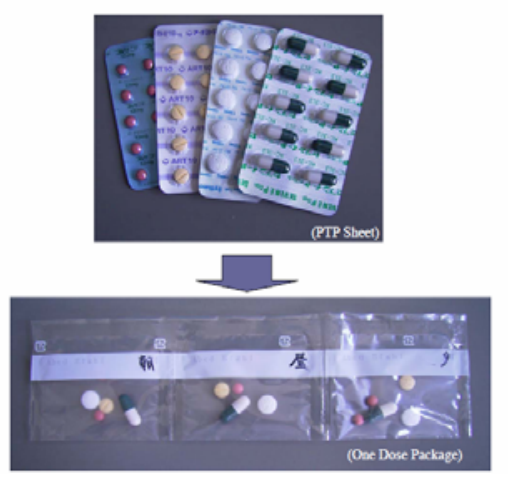

Figure 1. Example of One Dose Package.

Medication for the elderly distinctively involves multi-drug combination due to multiple complications with aging, giving rise to problematic situations with risks of duplicate medication and drug interaction. ${ }^{2}$ In addition, it is also characteristic that vision disorder, hearing loss and swallowing difficulty due to aging bring the condition requiring assistance.

According to the survey of medical care activity in public health insurance in $2006^{3}$, which was conducted by Ministry of Health, Labor and Welfare (MHLW), the number of medicine to a patient in medical care for the elderly was large in comparison with general medical care. The monitoring survey of Medicine and the Elderly in 2005 revealed that the larger the number of medication was, the more the missing dose increased. ${ }^{4}$ It was shown in the research report on the medication status for elderly that the higher the age was, the worse the medication adherence was. ${ }^{5}$

Deterioration of the medication adherence for elderly could result in wasteful medical expenditure in a long-term span as well as aggravating the patient's medical condition. Such a status of medical care for the elderly needs to be improved.

We surveyed the effect of one-dose package medication made up by a pharmacist on the patient's behavior towards medication, is expected to be one of the measures to improve the medication adherence for elderly.

\section{METHODS}

With support activity of the Pharmacist Association in Ueda-city in Nagano Prefecture, Japan, we surveyed the effect of one-dose package on the patient's behavior towards medication adherence. The survey form of one-dose package was sent to 86 pharmacy directors located in Ueda-city by fax and the answers were collected by fax on June 2007 . The collection rate was $86 \%$

This study surveyed pharmacist opinions regarding patients' medication adherence. However, in Japanese health care systems, pharmacist are required to make medication record for each patient which include detail patient information such as the history of medication, allergy and adverse event, summary of consultation with patients, medication adherence and condition of patients' health. We believe that these systems support the pharmacists understand the patient medication adherence.

\section{RESULTS}

The prescription number which the pharmacies accepted on April of 2007 was 85,239 (the average prescription number per pharmacy was 1,183 ) and the patients visit were 63,907 . One dose package of those prescriptions was 14,535 . In those one dose package, the reimbursed dispense as additional fee for one dose package add on the usual dispense fee are 2,028 which is only accounted for $14 \%$ of all of one dose package $(14,535)$. The most frequent age of patient who received as one dose package was over the 75 years old and it runs up to $41 \%$ of all of the prescriptions (Table 1).

\begin{tabular}{|c|c|}
\hline \multicolumn{2}{|c|}{$\begin{array}{l}\text { Table 1. The age structure of the patients who received } \\
\text { one dose package }\end{array}$} \\
\hline Age & Number of patients (\%) \\
\hline Over 75 & $5,802(41 \%)$ \\
\hline 6574 & $2,878(20 \%)$ \\
\hline 6064 & $1,205(8 \%)$ \\
\hline Under 60 & $4,487(31 \%)$ \\
\hline Total & $14,372(100 \%)$ \\
\hline
\end{tabular}

In the survey form, we asked the reason on one dose package from five prepared answers; "Request from patient", "Large number of doses", "Order by physician", "Prevent improper use" and "Improve medication adherence". The most frequent reasons of one dose packaging was "Patient's request". There were reasons that "Large number of doses", "Prevent the improper drug use" and "Improved medication adherence" which is considered that the pharmacists are willing to utilize one dose package for patient's care in order to improve the medication adherence and optimize the medication therapy. These reasons were more frequent than physician's direction. This result shows that pharmacist does dispense one dose packaging by own decision, not by physician's order (Table 2).

\begin{tabular}{|c|c|}
\hline Reason & Number of Answers* \\
\hline Request from patient & 72 \\
\hline Large number of doses & 57 \\
\hline Order by physician & 53 \\
\hline Prevent improper use & 44 \\
\hline Improve medication adherence & 42 \\
\hline
\end{tabular}

In the survey form again, we asked pharmacist the influences of one dose package for patient's medication adherence with four degrees; "Much improved", "Improved but still needs more effort", "Not changed" and "Worsen". "Much improved" is 
most frequent answer and second is "Improved but still needs more effort" (Table 3). In this question, we were also asking free opinion on the influences of one dose package and there are positive comments, for instance, improved health conditions, feeling the comfortable with proper drug use and reducing improper medication.

Table 3 Improvement of Medication Adherence by One dose Package

\begin{tabular}{|l|c|}
\hline \multicolumn{1}{|c|}{ Medication Adherence } & Number of answers \\
\hline $\begin{array}{l}\text { Much improved } \\
\text { Improved but still needs more } \\
\text { effort }\end{array}$ & 54 \\
\hline Not changed & 50 \\
\hline Worsen & 7 \\
\hline
\end{tabular}

We surveyed the patient's opinion the pharmacist received so far as free comments. Patient's opinions about one dose package were favorite, e.g. they could take medicines according to doctor's prescription, and would reduce the opportunity of improper use, and therefore, it could improve their disease conditions by better medication adherence, and also it made easier for their family and home helper to check medication adherence. On the other hand, there were small negative opinions that it needed some space to keep the package of medicines, and producing big garbage from the package after taking the drug.

There were interesting opinions that small cooperative efforts by pharmacist and patient, such as labeling dosing instructions on each package, brought much improvement of patient satisfaction and also improved medication adherence.

\section{DISCUSSION}

The role of pharmacists have been expanded from dispense medication to management of medication therapy that pharmacist educate patients for understanding importance of medication therapy and significance each medication. Medications for elderly tend to have multi drug combinations that cause poor medication adherence due to the complicate medications dosages. Pharmacist should take measures for elderly patients to take medication easily such as one dose package as well as giving the education for patients to understand proper medication use and role of each medicine which they needs to take.
From study results, it was noticed that there are great improvement of patient's compliance by one dose package, and patients felt advantage to reduce the improper drug use as well. It also seems that patient wants additional services such as printing the number, the date and time for taking on package as well as one dose packaging itself.

It would be very interesting from this survey that pharmacist of community setting are conducting one dose package without insisting reimbursement. Pharmacists are willing to dispense one dose package even if the requirement of reimbursement doesn't meet.

The one dose package is good for patient health particularly for elderly though, we couldn't say any economics value of dispensing the one dose package by pharmacist such as reimbursement rate because we didn't evaluate the economic value of this activity. However, we can say that there should be some incentive for these pharmacist activity with appropriate value for improving the medication adherence which was shown in this survey as well as the result of many literature of one dose package by pharmacist. ${ }^{6-8}$ We think that more research activities on the appropriate value of pharmacist for patient care should be conducted to be able to consider the appropriate economic incentive for pharmacist to have better health condition with proper drug use.

In Japan, we will have bigger aging society in near future, and new health care system for elderly person has introduced in 2008 by the Law of Elderly Health Care System (Law No. 70, Aug. 17 1982). Safe and cost effective medication therapy is one of the themes for the new healthcare system for elderly. ${ }^{9}$ Therefore, we need comprehensive study on the improving medication adherence by such as patient education and consultation for optimizing medication therapy. Originally, pharmacists are expected to manage outpatient's medication therapy for elderly by the patient education and consultation, and also optimize the drug use. ${ }^{1}$ From this survey, we can say that we should utilize the ability of pharmacist much more to provide the care of medication therapy management for elderly.

\section{CONFLICT OF INTEREST}

None declared.

\section{References}

1. Koichiro Harada, Improvement of drug adherence with pharmacist, Circulation Plus 2007;7(11):10-12.

2. Murray MD, Birt JA, Manatunga AK, Darnell JC. Medication compliance in elderly outpatients using twice-daily dosing and unit-of-use packaging. Ann Pharmacother. 1993;27(5):616-621.

3. Ministry of Health, Labor and Welfare, The survey of medical care activity in public health insurance in 2006, http://www.mhlw.go.jp/toukei/saikin/hw/sinryo/tyosa06/2-4.html (accessed 30-Oct-2008).

4. The monitoring survey of Medicine and the Elderly in 2005, The Woman's Executive Committee, Japan Federation of Senior Citizen's Club.

5. The report for medication adherence in elderly in 2004, Japan Pharmacist Association.

6. Schneider PJ, Murphy JE, Pedersen CA. Impact of medication packaging on adherence and treatment outcomes in older ambulatory patients. J Am Pharm Assoc (2003). 2008;48(1):58-63.

7. Connor J, Rafter N, Rodgers A. Do fixed-dose combination pills or unit-of-use packaging improve adherence? A systematic review. Bull World Health Organ. 2004;82(12):935-939 
8. Kripalani S, Yao X, Haynes RB. Interventions to enhance medication adherence in chronic medical conditions: A systematic review. Arch Intern Med. 2007;167(6):540-550.

9. Special Committee on health care system for the latter-stage elderly of Social Security Council, Medical fee scheme of health care system for the latter-stage elderly, Oct., 10 2007, http://www.mhlw.go.jp/shingi/2007/10/dl/s1010-7a.pdf (accessed 30-Oct-2008). 